\title{
A Comparative Study Between Chinese and Western Dragon Culture in Cross-Cultural Communication
}

\author{
Lina Yuan and Yunling Sun*
}

\author{
College of Humanities and Sciences of Northeast Normal University \\ *Corresponding author. Email:422820075@qq.com
}

\begin{abstract}
This paper compared the differences between Chinese and Western "dragon" culture and emphasizes that crosscultural communication should focus on contrast and comparison between heterogeneous cultures. Through the detailed analysis of the origins, cultural connotations, and symbolic meanings of Eastern and Western dragons, as well as their cultural development, we attempt to find a reasonable solution to reduce adverse effects of cultural differences and promote cross-cultural communication.
\end{abstract}

Keywords: Comparative study, Cross-cultural communication, Dragon culture, Cultural difference.

\section{INTRODUCTION}

Chinese culture has a long history and rich cultural content. In the various traditional Chinese culture, the dragon culture always plays an important role. Dragon is a symbol of China. The Chinese nation is called the "country of the dragon" and the Chinese are known as the "dragon's descendants". Because dragon plays an important role in Chinese traditional culture, it should be valued and promoted in the process of cross-cultural communication. When disseminating Chinese culture to Westerners, due to restrictions of various conditions, it is unrealistic to transfer all Chinese culture to westerners. Under such a background, we should select characteristics and unique cultures.

Dragon is a typical representative of Chinese culture and plays a very important role in cross-cultural communication. Chinese dragon culture has its own uniqueness, but may have different cultural connotations in different countries. These may cause unnecessary contradictions in the process of cross-cultural communication. The contrast between Chinese and western dragon culture can make cross-cultural communication more smooth and natural, and can avoid some contradictions and embarrassment. Therefore, the contrast between Chinese and Western dragon culture can play an important role.

\section{OVERVIEW OF CHINESE AND WESTERN DRAGON}

\subsection{The Comparative History of the Development of Chinese and Western Dragon}

We assume that the Chinese dragon and the Western dragon were produced at about the same time. The birthplace of the Chinese dragon was Babylon was based on the spread of the legend of the Tiamat (5000 B. C.). This roughly the same age as the existence of Xiang Yang Long. Western historian Chester G. Starr said in his A History of the Ancient Wizard that the development of northern Chinese culture had followed its own path since Zhoukoudian era, much earlier than the Babylonian culture (Liu, 2015).

The Neolithic Age was an era of agricultural production. China's agriculture began with millet and rice. People needed rain, in order to have a good harvest, while they feared that the flood will cause the family to die. So people imagined something that can make rain and control water, and then connect the celestial phenomena with the presence of animals, and then produce the embryonic form of the dragon. In the feudal era, the Chinese dragon was only a symbol of royalty and mystery; for the grassroots, the dragon looked down upon all beings and to a large extent represented the personification of the natural might.

Dragon, with omnipresent tolerance, even if it is latent without losing force, provides a proper symbol for 
Chinese self-esteem and self-reliance. The dragon that represents the majesty of the emperor has become the past with the feudal monarchy, but in the modern history. It has turned a confident, powerful yet peaceloving new image.

\subsection{The Contrast of External Image and Function of Dragon}

The great Chinese dragon culture is reflected internal function. The dragon of China originally came from nature, but it was also drawn from nature.

From the perspective of function, Chinese and Western dragon cultures follow different tracks. But they act as an important role: to create hero legends. Whether in China or west, there are many people and legends about the dragon. First of all, the number of legends of Chinese dragons, increased dramatically, and had a great number of heroes of controlling dragon. These stories empowered emperors with authority and ability, which compared them to be dragons. The most popular version in Western society is the Legend of Dragon Slaying, although most of people are named the "Dragon Warrior" by hunting the evil dragons to be heroes. However, the dragons have similar functions in west and east. The dragon sets the Chinese emperors off keeping up their prestige. Western heroes are respected by killing dragon. It follows that the dragon is severed as a foil to a character. That's what they have in common on functionality.

The Chinese dragon stands for justice, compared to the evil image of the west. Therefore, the function of the Chinese dragon is certainly much greater than the function of the western dragon. It has many functions that the western "dragon" does not possess. Chinese dragon represented hope and people in ancient societies. During the feudal society, the Chinese dragon was used as a symbol of imperial power, which was majestic, sacred and solemn to contribute greatly to consolidating the ruler's dominance. In addition, in China's traditional folk beliefs and totem worship, dragon worship, dragon totem and dragon belief that have been admired by China since ancient times are even more widely disseminated through the minds of Chinese people.

Chinese and Western culture cultivated two "dragons" in different background, and they contrast to each other due to functions and values brought about by society. The Chinese dragon is a beast but its status is noble in folk beliefs. Western dragon is characterized by the evil and fierce image.

\section{EXPLORATION OF COMPARATIVE STUDY BETWEEN CHINESE AND WESTERN DRAGON CULTURE}

\subsection{Difference of Traditional Belief}

There are differences in traditional beliefs. In the West, people have endued dragons various images. People think that the dragon is a huge monster with huge wings, a deer-like horns, a sturdy body, the eagle's claws and a large painting nostril. It can run out of flame to burn the house. At the same time, dragon is also very alert, guarding the treasures of gold and silver and the important intersections in the legends do not pass. It is cruel and inhuman, killing human beings. Its appearance will only cause endless harm to mankind. The hero slays dragon is to promote justice, and warriors mark the supreme glory by killing the dragon.

As mentioned Bible, sin is the essence of dragons. Christians are proud to kill dragons. Therefore, Westerners think that the dragon is the embodiment of evil. In fact, despite the fact that the Christian faith has put Western dragons on a deep anti-stigmatization, for such creatures with terrible power, the ancient Europeans who are martial artists may fear the true attitude of Western dragons. In the Middle Ages or modern times, there were countless nobles with European dragon emblems. The early guns and artillery were also nominated by dragons or dragon-shaped monsters.

The Chinese dragon is beautiful can benefit the people and give rain to the earth, going into the sea and becoming the incarnation of justice, which is the incarnation of the cloud and rain. The dragon in the sky is thought to be a symbol of Auspicious. There are many legends about Chinese dragon and idioms, like crouching tiger, dragons flying and phoenixes dancing and so on.

\subsection{Different Expression in Film and Television Works}

In the western movies of recent decades, the dragon still appears as a traditional image of the "Treasure Guardian", but it has been given more neutral and even positive emotions so that human beings need to respect them. The Dragon Heart (1996) showed the first image of western dragon. The protagonist named Cang Dragon is a kind-hearted dragon. In 1998, Disney released the animated version of Mulan, there is the patron saint of the heroine -a cute, humorous and kind-hearted Chinese dragon which is named "Mushu". The "Mushu" differs from image of the solemn and sacred dragon, but it was among children all over the world. The blockbuster movie "Shrek" was very popular in 2001. There was a cute and passionate falling dragon in love with Shrek's friend (Gao, 2010). 
In 2005, the best-selling Harry Potter series are written by J.K Rowling sweep the world and are put on the screen. The dragon inside is mainly neutral and good and bad. In the Eragon (2006), the dragon is a companion of the dragon knight. In the D-war (2007), dragon is set up in such a way that the giant cymbals received sacred pearl incarnations of dragon, which is far from the Chinese dragon culture. In 2011, the image of Dragon in The Dragon Pearl was also close to that in Chinese mythology, and the whole body is magnificent. Due to cultural fusion, western dragons in modern European and American fantasy often have the dignity and spirituality of Chinese dragons. Chinese fantasy lovers also accept the concept of western dragons, and even recognize the use of "dragon" as the Chinese translation of "dragon".

In the classic movies and TV works of the East, there are many impressive videos. For example, the dragon in Little Dragon Boy is lovely and clever who caused disputes. In the Nezha Conquers the Dragon King, but the image of dragon leaping at the East China Sea is still full of uprightness. Like Little White Dragon and Dragon King of the East Sea in Journey to the West, they can dive into the sea, be tempted in sky, and have influence on climate between the mountain and clouds. The dragon used to be for god and man in the rituals of witchcraft. Later, it gradually became the god in control of the rain.

\section{INTERCULTURAL COMMUNICATION OF THE CHINESE AND WESTERN DRAGON}

\subsection{Differences between Chinese and Western Cultures in Communication Comprehension}

Regardless of appearance, ability or connotation, there is a great deal of disagreement between China Dragon and Western Dragon. Many foreigners have misunderstood Chinese dragon culture, confirming that both Chinese dragons and western dragons are evil representatives. This misunderstanding leads to the difficulty to know about the Chinese national spirit of harmony, which finally undermined China's international image.

In the 1990s, Westerners" "Red Dragon Theory" paid great attention to the threat of China. They said that socialist China is a red grenade for the rise of the East and inevitably brought bad luck to the West. At the 29th Olympic Games, the Chinese dragon as a mascot was supported by Chinese people at home and abroad. Surprisingly, the Chinese dragon was not selected. BOCOG (Beijing Organizing Committee for the Olympic Games) explained that the dragon has a different understanding in the world.
Different interpretations have different translations. Translation is a very important part of cross-cultural communication. When people of different languages communicate with each other, translation is absolutely inseparable. But whether the translation is good or bad is difficult to define. Sometimes it is too faithful to the original, leading to people cannot clearly understand the target language country in many unique primitive slang and common psychological cognition. For example, the "Asian Four Little Dragons" is translated into "Four Asian Tiger" instead of "Four Asian Dragon", which means the different values between China and the West.

The different interpretation of the "Dragon" is just a microcosm of cultural differences between China and the West. In cross-cultural communication, in the face of the collisions between different cultures in China and the West, in general, we should adopt a "cross-cultural" concept of "harmony". The so-called "harmony" is "harmony but not the same". This is an open, inclusive attitude that seeks common ground while reserving differences. We must not only fully understand Western culture and absorb all progressive culture beneficial to the development of Chinese culture, but also fully realize that the unique characteristics of China, through dialogues and exchanges promote the development of cultures, and contribute to the prosperity of the world (Le, 1995).

\subsection{Differences between Chinese and Western Culture in Customs}

As Chinese place their auspicious ideals on the body of the dragon, this creature naturally becomes their beast in spirt. There is a famous folk - "prosperity brought by the dragon and the phoenix", where the "dragon" is a symbol of auspiciousness, harmony, longevity and noble.

As a symbol of nobility, "dragon" shows that in the Lantern Festival or Spring Festival, citizens always play dragon lanterns and lion dances, reflecting their belief that "dragon" performs the role in avoiding evils. People believe there is the blessing of the dragon can avoid all disasters and evils and ensure peace forever. Chinese folks also hold dragon boat races and dragon dance to celebrate festival and to pray for good weather. Today, there are countless, folk customs, and ethnic festivals in China that are related to the dragon.

For example, the second day of February in the lunar calendar was called "Dragon-Heads-raising Festival", which is the time for the dragon to rise and fall. It is said that the festival is characterized by good weather. Thus, there is a folk song "February 2, dragon rises head, big warehouse is full, small granary stream". The Yao nationality in their festival sacrifices pigs for offerings on the third day of the third month of the lunar calendar. The pigs are killed for the purpose of sacrificing 
dragons and keeping people and animals safe. The August 18th of the lunar calendar is recognized as the day of the god of Dragon King. On this day, people pray that people would be blessed with good weather throughout the year by the Dragon King. The Western Dragon has no customs related to dragons according to literature review ( $\mathrm{Ji}, 2002)$.

\section{CONCLUSION}

This article takes the dragon's profile and culture as research subject and conducts a comparative analysis of the differences between Chinese and Western dragon cultures. These elements cause unnecessary conflicts and contradictions. In fact, as understanding of these differences can advance the process of cross-cultural communication and strengthen the political, economic, and cultural exchanges between China and the West. Numerous documents on the study of Chinese dragon culture, but there are few studies on the external communication of dragon culture and in cross-cultural communication. Likewise, there are many research literatures about dragon culture in the West, but there are few literatures that compare with Chinese dragon culture. This leads to the idea of analyzing this aspect.

\section{REFERENCES}

[1] Venuti, Lawrence. The Translator's Invisibility-A History of Translation [M]. London and New York: Routledge, 1995.

[2] Webster's Dictionary of American English [Z]. Random House. FLTRP, 1997.

[3] Werner J. Severin, James W.Tankard, Jr. The Clash of Civilizations and Remaking of World Order [J]. Allyn \& Bacon, 2000, (07): 55-60.

[4] Yuan Liu. Cultural Differences of 1.1. Second Level Heading (Head 2).
[5] Encyclopaedia Americana [Z]. Danbury Connecticut Grolier Incorporated, 1988.

[6] Grace, Edwards. Reflections on Creating a Cultural History of Chinese Australian Community [J].Chinese Southern Diaspora Studies, 2013:102104.

[7] Grice, H.P. logic and conversation [M]. The Semantics-Pragmatics in Philosophy, 2013.

[8] Gudykunst, W. B [M]. Cross-cultural and intercultural communication. Thousand Oaks: Sage, 2003.

[9] John Simpson and Edmund Weiner. Oxford English dictionary [M].Clarendon, 1993.

[10] Jakob Nielsen. Designing Web Usability: The Practice of Simplicity, 1stedition [M]. New Riders Press, 1999, (8).

[11] Oxford Advanced Learner's English-Chinese Dictionary [Z]. Ox-ford University, 1965.

[12] Philosophy Simpson and Edmund Weiner [J]. Oxford English dictionary, England C-larendon, 1993: 101-105.

[13] Venuti, Lawrence. The Translator's Invisibility-A History of Translation [M]. London and New York: Routledge, 1995.

[14] Webster's Dictionary of American English [Z]. Random House. FLTRP, 1997.

[15] Werner J.Severin, James W.Tankard, Jr. The Clash of Cicilizations and Remaking of World Order [J]. Allyn \& Bacon, 2000, (07):55-60.

[16] Yuan Liu. Cultural Differences of Chinese Loong and Western Dragon [J]. CSCanada, 2015, (03):4043. 